\title{
METODE PEMBINAAN AKHLAK DALAM PENINGKATAN PENGAMALAN IBADAH PESERTA DIDIK DI SMP N 4 SEKAMPUNG LAMPUNG TIMUR
}

\author{
BAYU PRAFITRI \& SUBEKTI \\ STIS Darul Ulum Lampung Timur, \& IAIN Metro \\ bambangismanto780@gmail.com \&, subekty999@gmail.com,
}

\begin{abstract}
Abstrak
Islamic religious education teachers are people who provide knowledge with the aim of educating and fostering the morality of students as good people. In the process of moral development of students, an Islamic education teacher must have the right method, because they have an important role in it. Based on the background, the author wants to discuss it with the purpose to determine the method of the teachers in developing moral of the students. The research is descriptive qualitative research, and in the course of collecting data, the author uses observation, documentation, and interview methods. While for the analysis, the author uses qualitative descriptive analysis techniques, describing thoroughly about the actual situation. The results of the research conducted by the author can be conveyed here, that the coaching method that the author offers in developing the students' morals are asking students to read al-qur'an, praying for them, asking to practice directly, giving tasks to make notes about the Ramadhan activities, giving advises, making as habits, giving examples, suggesting to choose good friends, and giving rewards or punishment.

Keyword: methods, morals, worship and students
\end{abstract}

\begin{abstract}
Abstrak
Guru Pendidikan agama Islam merupakan orang yang memberikan ilmu pengetahuan dengan tujuan mencerdaskan dan membina akhlak peserta didik agar menjadi orang yang berkepribadian baik. Dalam proses pembinaan akhlak peserta didik, seorang guru pendidikan agama Islam harus memiliki metode yang tepat karena memegang peranan yang pertama dan utama dalam proses pembinaan akhlak peserta didiknya. Berangkat dari latar belakang itulah, penulis ingin mengetahui metode guru pendidikan agama Islam. Penelitian merupakan bentuk penelitian kualitatif deskriptif, dengan melakukan pengumpulan data melalui observasi, dokumentasi, dan wawancara. Sedangkan untuk analisisnya, digunakan teknik analisis deskriptif kualitatif, yaitu: berupa data-data yang tertulis atau lisan dari orang dan perilaku yang diamati sehingga dalam hal ini penulis berupaya mengadakan penelitian yang bersifatmenggambarkan secara menyeluruh tentang keadaan yang sebenarnya. Dari hasil penelitian yang telah dilakukan diperoleh data bahwa guru melakukan beberapa dalam membina akhlak siswa, yakni melalui mengajak siswa membaca surat-surat pendek dalam alqur'an, mendoakan siswa dengan cara mengucapkan salam, mengajak langsung praktek ke lapangan, memberikan tugas mencatat kegiatan kegiatan ramadhan, melalui pelajaran atau nasihat, membiasakan akhlak yang baik, melalui keteladanan yang baik, menyarankan untuk memilih teman yang baik, dan memberi reward atau sangsi.
\end{abstract}

Kata Kunci: metode, akhlak, ibadah dan siswa 


\section{PENDAHULUAN}

Pendidikan merupakan kebutuhan manusia, kebutuhan pribadi seseorang. Kebutuhan yang tidak dapat diganti dengan yang lain. Karena pendidikan merupakan kebutuhan setiap individu untuk mengembangkan kualitas, pontensi dan bakat diri. Pendidikan membentuk manusia dari tidak mengetahui menjadi mengetahui, dari kebodohan menjadi kepintaran dari kurang paham menjadi paham, intinya adalah pendidikan membentuk jasmani dan rohani menjadi paripurna. Sebagaimana tujuan pendidikan, menurut Sistem Pendidikan Nasional (SISDIKNAS) UU RI NO. 20 TH. 2003 BAB II Pasal 3 dinyatakan bahwa :"Pendidikan nasional berfungsi mengembangkan kemampuan dan membentuk watak serta peradaban bangsa yang bermartabat dalam rangka mencerdaskan kehidupan bangsa, bertujuan untuk berkembangnya potensi peserta didik agar menjadi manusia yang beriman dan bertakwa kepada Tuhan Yang Maha Esa, berakhlak mulia, sehat, berilmu, cakap, kreatif, mandiri, dan menjadi warga Negara yang demokratis serta bertanggung jawab"."

Tujuan pendidikan setidaknya terbagi menjadi dua, yaitu pendidikan bertujuan mengembangkan aspek batin/rohani dan pendidikan bersifat jasmani/ lahiriyah. Pendidikan bersifat rohani merujuk kepada kualitas kepribadian, karakter, akhlak dan watak, kesemua itu menjadi bagian penting dalam pendidikan, kedua pengembangan terfokus kepada aspek jasmani, seperti ketangkasan, kesehatan, cakap, kreatif. Pengembangan tersebut dilakukan di institusi sekolah dan di luar sekolah seperti di dalam keluarga, dan masyarakat.

Pendidikan adalah usaha sadar dan terencana untuk mewujudkan suasana belajar dan proses pembelajaran agar peserta didik secara aktif mengembangkan potensi dirinya untuk memiliki kekuatan spiritual keagamaan, pengendalian diri, kepribadian, kecerdasan, akhlak mulia serta keterampilan yang diperlukan dirinya, masyarakat, bangsa dan negara. ${ }^{2}$

Tujuan pendidikan berusaha membentuk pribadi berkualitas baik jasmani dan rohani. Dengan demikian secara konseptual pendidikan

1 Redaksi Sinar Grafika, Undang-Undang Sistem Pendidikan Nasional, UU RI NO.20

Tahun.2003 (Jakarta: Sinar Grafika, 2003), hlm. 5-6, http://buku-rahmadetail.blogspot.com/2014/09/undang-undang-sisdiknas-sistem.html.

${ }^{2}$ Dewan Perwakilan Rakyat Republik Indonesia Dan Presiden Republik Indonesia, Undang-undang Republik Indonesia Nomor 20 tahun 2003 tentang Sistem Pendidikan Nasional (Bandung: Fokus Media, 2006), hlm. 2. 
mempunyai peran strategis dalam membentuk anak didik menjadi manusia berkualitas, tidak saja berkualitas dalam segi skill, kognitif, afektif, tetapi juga aspek spiritual. Hal ini membuktikan pendidikan mempunyai andil besar dalam mengarahkan anak didik mengembangkan diri berdasarkan potensi dan bakatnya. Melalui pendidikan anak memungkinkan menjadi pribadi soleh, pribadi, berkualitas secara skill, kognitif dan spiritual.

Dari pengertian tersebut tergambar adanya proses pembelajaran terhadap peserta didik agar mengembangkan potensi dirinya untuk memiliki kekuatan spiritual keagamaan. Hal ini mengindikasikan betapa pentingnya pendidikan agama untuk mendukung peserta didik memiliki kekuatan spiritual tersebut.

Sebagaimana diterangkan dalam firman Allah dalam al-Qur'an :

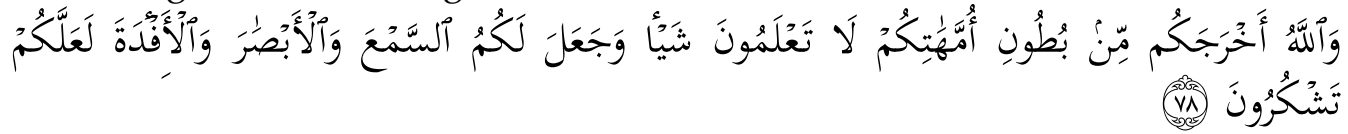

Artinya : Dan Allah mengeluarkan kamu dari perut ibumu dalam keadaan tidak mengetahui sesuatupun, dan dia memberi kamu pendengaran, penglihatan dan hati, agar kamu bersyukur. ( QS. An-Nahl : 78) $)^{3}$

Agar anak mempunyai akhlak yang mulia, anak didik diharapkan dapat memperhatikan pelajaran berbasis agama sebagai kontrol dalam kehidupan anak didik.

Dalam sejarah perkembangan Islam, pada periode permulaan dakwah Nabi Muhammad SAW. Tidak langsung menuntut sahabat-sahabatnya mengamalkan syariat Islam secara sempurna sebagai yang dijabarkan dalam lima rukun Islam, akan tetapi selama 10 tahun di Makkah beliau mengajarkan Islam lebih dahulu menitik beratkan pada pembinaan landasan fundamental yang berupa keimanan dan keyakinan kepada Allah SWT. Karena dari landasan inilah manusia akan berakhlak yang baik.

Pendidikan Islam sebagai usaha membina dan mengembangkan pribadi manusia dari aspek-aspek kerohanian dan jasmaninya juga harus berlangsung secara bertahap. Oleh karena suatu pematangan yang bertitik akhir pada optimalisasi perkembangan atau pertumbuhan, baru dapat tercapai bilamana berlangsung melalui proses demi proses ke arah tujuan hlm. 275 .

${ }^{3}$ Departemen Agama RI, Al-Qur'an dan Terjemahannya (Bandung: Jum'anatul Art, 2005), 
akhir perkembangan atau pertumbuhannya. ${ }^{4}$ Dari beberapa pengertian di atas, penulis dapat menyimpulkan bahwa pendidikan agama Islam adalah bimbingan jasmani dan rohani berdasarkan al-Quran terhadap anak-anak agar terbentuk kepribadian muslim yang sempurna.

Pendidikan agama merupakan suatu sistem pendidikan yang mencakup seluruh aspek kehidupan yang dibutuhkan oleh umat manusia dalam rangka meningkatkan penghayatan dan pengalaman agama dalam kehidupan bermasyarakat, beragama, berbangsa dan bernegara.

Pendidikan agama Islam merupakan bagian yang tak terpisahkan dari sistem pendidikan di Indonesia, sebagaimana yang tercantum dalam Undang-undang nomor 20 tahun 2003 tentang Sistem Pendidikan Nasional pasal 12 ayat 1 butir a "Setiap peserta didik pada setiap satuan pendidikan berhak mendapatkan pendidikan agama sesuai dengan agama yang dianutnya dan diajarkan oleh pendidik yang seagama". ${ }^{5}$ Dengan demikian pendidikan sangat penting bagi kelangsungan hidup di dunia dan di akhirat. Pendidikan jugalah yang akan membuat pengetahuan manusia berkembang.

Sedangkan pendidikan agama diartikan sebagai suatu kegiatan yang bertujuan untuk membentuk manusia agamis dengan menanamkan aqidah keimanan, amaliah dan budipekerti atau akhlak yang terpuji untuk menjadi manusia yang takwa kepada Allah SWT. ${ }^{6}$

Dalam standar kompetensi mata pelajaran Pendidikan Agama Islam yang berisi kemampuan minimal yang harus dikuasai peserta didik selama menempuh PAI di SMP, kemampuan ini berorientasi pada perilaku afektif dan psikomotorik dengan dukungan pengetahuan kognitif dalam rangka memperkuat keimanan dan ketakwaan kepada Allah SWT. PAI adalah mata pelajaran yang tidak hanya mengantarkan peserta didik dapat menguasai berbagai kajian keislaman, tetapi PAI lebih menekankan bagaimana peserta didik mampu menguasai kajian keislaman tersebut sekaligus dapat mengamalkannya dalam kehidupan sehari-hari di tengah-tengah

4 M. Arifin, Filsafat pendidikan Islam (Jakarta: Bumi Aksara, 1997), hlm. 10, https://books.google.co.id/books?id=-

101AgAACAAJ\&dq=M.+Arifin,+M.Ed,+Filsafat+Pendidikan+Islam\&hl=en\&sa=X\&ved=0ahUKEwiy zLLPiMzfAhWIMY8KHdr9BcYQ6AEIKTAA.

${ }^{5}$ Arifin, Filsafat pendidikan......, hlm. 8.

${ }^{6}$ M. Basyiruddin Usman, Metodologi Pembelajaran Agama Islam, cet. ke-1 (Jakarta: Ciputat Pers, 2002), hlm. 4. 
masyarakat. Dengan demikian, PAI tidak hanya menekankan pada aspek kognitif saja, tetapi yang lebih penting adalah pada aspek afektif dan psikomotornya. ${ }^{7}$ Metode Pembinaan Akhlak yang dilakukan guru Pendidikan Agama Islam pada SMP N 4 Sekampung Lampung Timur telah berjalan sesuai dengan program yang telah ditentukan. Namun dari hasil pra survey yang penulis lakukan pada sekolah tersebut diperoleh gambaran ternyata kondisi peserta didik masih cukup banyak yang memiliki akhlak dan kemampuan beribadah yang kurang baik.

Berdasarkan hasil wawancara penulis dengan Ibu Sumini selaku guru mata pelajaran PAI di SMP N 4 Sekampung Lampung Timur yang mengatakan "dalam proses pembinaan akhlak, beberapa metode telah saya terapkan, mulai dari memberi contoh sampai memberikan hukuman ketika tidak menaati apa yang telah ditetapkan sekolah. Tetapi peserta didik masih saja ada yang menyimpang dari prilaku yang tidak sesuai dengan konsep materi pembelajaran dikelas maupun diluar kelas"8 Dari hasil wawancara penulis dengan Guru PAI tersebut di atas, maka penulis mendapatkan gambaran bahwa hasil pembinaan akhlak serta materi pembelajaran PAI, ternyata belum mencapai hasil yang optimal. Hasil pembinaan akhlak serta materi pembelajaran PAI belum membentuk peserta didik yang memiliki akhlak dan kemampuan beribadah yang cukup baik, sesuai dengan tujuan dan harapan pembelajaran PAI. Dalam hal akhlak di antaranya yaitu terlihat beberapa peserta didik yang memiliki akhlak yang kurang baik, cenderung mengikuti pergaulan teman yang kurang baik semisal berkata-kata yang buruk, kurang menghormati orang yang lebih tua dan kurang menaati peraturan sekolah semisal : membolos dan tidak berpakaian dengan rapi. ${ }^{9}$

Dari hasil wawancara dengan Guru PAI, penulis juga mendapat keterangan mengenai kemampuan beribadah peserta didik. Sumini selaku guru PAI mengatakan bahwa "dalam hal beribadah, ada juga di antaranya beberapa peserta didik yang belum bisa melaksanakan sholat dengan benar, belum bisa mengaji al-Qur'an dengan baik serta belum bisa membaca do'a setelah sholat". ${ }^{10}$ Dengan demikian, mencermati hal di atas maka penulis akan

${ }^{7}$ Usman, Metodologi Pembelajaran...., hlm. 3.

${ }^{8}$ Sumini, Guru PAI SMP N 4 Sekampung Lampung Timur, Pembinaan Akhlak, , Tanggal 17 Juli 2014, t.t.

${ }^{9}$ Observasi, tanggal 17 Juli 2014

${ }^{10}$ Sumini, Guru PAI SMP N 4 Sekampung Lampung Timur, Ibadah dan Sholat, Tanggal 12Maret 2014. 
mencoba menyoroti Metode pembinaan akhlak yang digunakan guru PAI di SMP N 4 Sekampung Lampung Timur, yang ditekankan pada aspek pembinaan akhlak dan ibadah pada peserta didik.

\section{METODE PENELITIAN}

Penelitian ini menggunakan pendekatan kualitatif, diharapkan terangkat gambaran mengenai kualitas, realitas sosial dan persepsi sasaran penelitian tanpa tercemar oleh pengukuran formal. Penelitian didasarkan pada persepsi emik untuk mengungkapkan dan mengurangi sistem dan perilaku bersama satuan strukturnya dan kelompok struktur satuan-satuan itu. ${ }^{11}$ Sumber data dipilih secara purposive sampling yakni orang-orang yang dianggap sangat mengetahui permasalahan yang akan diteliti atau juga yang berwenang dalam masalah tersebut. Dalam pengumpulan data dilakukan pada natural setting (kondisi yang alamiah), sumber data primer, dan teknik pengumpulan data yaitu observasi non partisipan (non participan observation), wawancara mendalam (in depth interivew), dan dokumentasi. Analisis data yang digunakan dalam penelitian ini adalah dilakukan sepanjang kegiatan penelitian, penyederhanaan data (data reduction), penyajian data (data display), dan menarik kesimpulan (making conclusion).

\section{DEKRIPSI TEORITIS}

\section{Metode Pembinaan Akhlak Guru Pendidikan Agama Islam}

Ada 6 (enam) metode pembinaan akhlak dalam perspektif Islam; metode yang diambil dari al-Qur'an dan Hadis, serta pendapat pakar pendidikan Islam, yakni memberi teladan, pembiasaan, nasehat, ceritera, perumpamaan, dan ganjaran.

\section{Metode Uswah (teladan)}

Teladan adalah sesuatu yang pantas untuk diikuti, karena mengandung nilai-nilai kemanusiaan. Manusia teladan yang harus dicontoh dan diteladani adalah Rasulullah SAW, sebagaimana firman Allah SWT dalam surah al-Ahzab ayat 21 :

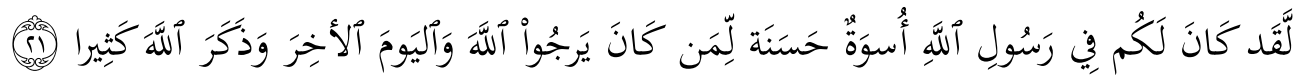

${ }^{11}$ Dennis Philip Forcese dan Stephen Richer, Social Research Methode (New Jersey: Hall IncEned Wood Cliffs, 1973), hlm. 3. 
Artinya: Sesungguhnya telah ada pada (diri) Rasulullah itu suri teladan yang baik bagimu (yaitu) bagi orang yang mengharap (rahmat) Allah dan (kedatangan) hari kiamat dan Dia banyak menyebut Allah.

Jadi, sikap dan perilaku yang harus dicontoh, adalah sikap dan perilaku Rasulullah SAW, karena sudah teruji dan diakui oleh Allah SWT.

\section{Metode Ta'widiyah (pembiasaan)}

Metode ta'widiyah atau pembiasaan secara etimologi asal katanya adalah biasa. Dalam Kamus Umum Bahasa Indonesia, biasa artinya lazim atau umum ; seperti sedia kala; sudah merupakan hal yang tidak terpisahkan dalam kehidupan sehari-hari. Muhammad Mursyi dalam bukunya "Seni Mendidik Anak", menyampaikan nasehat Imam al-Ghazali : "Seorang anak adalah amanah (titipan) bagi orang tuanya, hatinya sangat bersih bagaikan mutiara, jika dibiasakan dan diajarkan sesuatu kebaikan, maka ia akan tumbuh dewasa dengan tetap melakukan kebaikan tersebut, sehingga ia mendapatkan kebahagiaan di dunia dan akhirat"

\section{Metode Mau'izhah (nasehat)}

Kata mau'izhah berasal dari kata $w a^{\prime} z h u$, yang berarti nasehat yang terpuji, memotivasi untuk melaksanakannya dengan perkataan yang lembut. Allah berfirman dalam surah al-Baqarah ayat 232 :

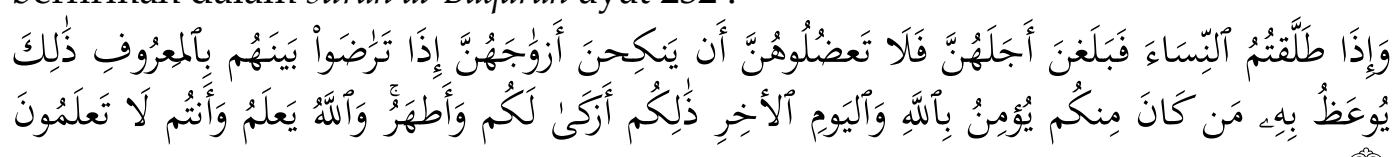

Artinya: Itulah yang dinasehatkan kepada orang-orang yang beriman di antara kamu kepada Allah dan hari kemudian. itu lebih baik bagimu dan lebih suci. Allah mengetahui, sedang kamu tidak mengetahui.

\section{Metode Qishshah (ceritera)}

Qishshah dalam pendidikan mengandung arti, suatu cara dalam menyampaikan materi pelajaran, dengan menuturkan secara kronologis, tentang bagaimana terjadinya sesuatu hal, baik yang sebenarnya terjadi ataupun hanya rekaan saja. Dalam pendidikan Islam, ceritera yang bersumber dari al-Qur'an dan Hadis merupakan metode pendidikan yang sangat penting, alasannya, ceritera dalam al-Qur'an dan Hadis, selalu memikat, menyentuh perasaan dan mendidik perasaan keimanan, contoh, surah Yusuf, surah Bani Israil dan lain-lain. Metode Amtsal (perumpamaan) 
Metode perumpamaan adalah metode yang banyak dipergunakan dalam al-Qur'an dan Hadis untuk mewujudkan akhlak mulia. Allah SWT berfirman dalam surah al-Baqarah ayat 17 :

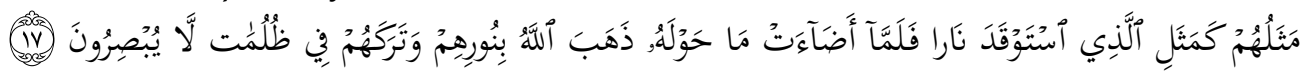

Artinya: Perumpamaan mereka adalah seperti orang yang menyalakan api. Maka setelah api itu menerangi sekelilingnya Allah hilangkan cahaya (yang menyinari) mereka, dan membiarkan mereka dalam kegelapan, tidak dapat melihat.

\section{Metode Tsawab (ganjaran)}

Metode tsawab itu diartikan sebagai hadiah dan bisa juga hukuman. Metode ini juga penting dalam pembinaan akhlak, karena hadiah dan hukuman sama artinya dengan reward and punisment dalam pendidikan Barat. Hadiah bisa menjadi dorongan spiritual dalam bersikap baik, sedangkan hukuman dapat menjadi remote control, dari perbuatan tidak terpuji.

\section{Pendidikan Agama Islam}

\section{Pengertian Pendidikan Agama Islam}

Pendidikan berasal dari kata "didik", lalu kata ini mendapat awalan pedan akhiran -an sehingga menjadi "pendidikan", yang artinya "Proses pengubahan sikap dan tata laku seseorang atau kelompok orang dalam usaha mendewasakan manusia, melalui upaya pengajaran dan pelatihan ; atau proses perbuatan, cara mendidik". ${ }^{2}$ Adapun pengertian pendidikan menurut Muhibbin Syah, yaitu memelihara dan memberi latihan. Dalam memelihara dan memberi latihan diperlukan adanya ajaran, tuntunan dan pimpinan mengenai akhlak dan kecerdasan pikiran. ${ }^{13}$ Dalam bahasa Inggris, Education pendidikan berasal dari kata educate (mendidik) artinya memberi peringatan (to elicit, to give rise to ), dan mengembangkan (to evolve, to develop). Dalam pengertian yang sempit, Education atau pendidikan berarti perbuatan atau proses perbuatan untuk memperoleh pengetahuan. ${ }^{14}$ Pendidikan dalam konteks Islam pada umumnya mengacu kepada term at-Tarbiyah, at-Ta'dib dan at-Ta'lim. Dari ketiga istilah tersebut terminologis yang paling populer digunakan dalam praktek pendidikan Islam

${ }^{12}$ Departemen Diknas, Kamus Besar Bahasa Indonesia, Cet. ke-3 (Jakarta: Balai Pustaka, 1994), hlm. 232.

${ }^{13}$ Muhibbin Syah, Psikologi Pendidikan dengan Pendekatan Baru, cet. ke-7 (Bandung: PT. Remaja Rosdakarya, 2002), hlm. 10.

${ }^{14}$ Syah, Psikologi Pendidikan dengan..., hlm. 10. 
ialah term at-tarbiyah, sedangkan term at-ta'dib dan at-ta'lim jarang sekali digunakan. Padahal kedua istilah tersebut telah digunakan sejak awal pertumbuhan pendidikan Islam. ${ }^{15}$

Sedangkan menurut istilah, pendidikan Islam adalah suatu sistem kependidikan yang mencakup seluruh aspek kehidupan yang dibutuhkan oleh hamba Allah. Oleh karena Islam memedomani seluruh aspek kehidupan manusia muslim baik duniawi maupun ukhrawi. ${ }^{16}$ Ahmad D. Marimba mengemukakah bahwa pendidikan Islam adalah bimbingan atau pimpinan secara sadar oleh pendidik terhadap perkembangan jasmani dan rohani peserta didik menuju terbentuknya kepribadiannya yang utama (insan kamil). ${ }^{17}$ Sedangkan Ahmad Tafsir mendefinisikan pendidikan Islam sebagai bimbingan yang diberikan oleh seseorang (peserta didik)agar ia berkembang secara maksimal sesuai dengan ajaran Islam. ${ }^{18}$

Dari pengertian di atas, dapat disimpulkan bahwa pendidikan Islam adalah suatu sistem yang memungkinkan seseorang (peserta didik) dapat mengarahkan kehidupannya sesuai dengan ideologi Islam.

\section{Dasar dan Tujuan Pendidikan Agama Islam}

Dasar adalah landasan untuk berdirinya sesuatu, fungsi dasar ialah memberikan arah kepada tujuan yang akan dicapai dan sekaligus sebagai landasan untuk berdirinya sesuatu. ${ }^{19}$ Dasar pendidikan agama Islam dapat ditinjau dari segi yuridis / hukum dan dasar religius. Dasar yuridis/ hukum, yang tercakup dalam segi ini adalah 1) Landasan ideal Pancasila, sila pertama Ketuhanan Yang Maha Esa mengandung pengertian bahwa seluruh bangsa Indonesia harus percaya kepada Tuhan Yang Maha Esa atau dengan kata lain harus beragama. 2) Landasan Struktural/ konstitusional yakni UUD 1945 dalam Bab XIPasal 29 ayat1 dan 2 berbunyi :20

\footnotetext{
${ }^{15}$ Samsul Nizar, Filsafat Pendidikan Islam, Pendekatan Historis, Teoritis dan Praktis, cet. ke-1 (Jakarta: Ciputat Pers, 2002), hlm. 25.

${ }^{16}$ Arifin, Filsafat pendidikan Islam, hlm. 10.

${ }^{17}$ Ahmad D Marimba, Pengantar Filsafat Pendidikan Islam (Bandung: Al-Ma'arif, 1989), hlm. 19.

${ }^{18}$ Ahmad Tafsir, Ilmu Pendidikan dalam Perspektif Islam, cet. ke-1 (Bandung: Remaja Rosdakarya, 1992), hlm. 32.

${ }^{19}$ Samsul Nizar, Pengantar Dasar-dasar Pemikiran Pendidikan Islam (Jakarta: Gaya Media Pratama, 2000), hlm. 95.

${ }^{20}$ dewan Perwakilan Rakyat Republik Indonesia, Undang-undang Dasar 1945 HasilAmandemen, cet. ke-2 (Jakarta: Sinar Grafika, 2005), hlm. 24.
} 
(1) Negara berdasarkan atas Ketuhanan Yang Maha Esa

(2) Negara menjamin kemerdekaan tiap-tiap penduduk untuk memeluk agamanya masing-masing dan untuk beribadat menurut agamanya dan kepercayaannya itu.

Adapun Landasan Operasionalnya yakni dasar yang secara langsung mengatur pelaksanaan pendidikan agama di sekolah-sekolah di Indonesia, yakni Undangundang Republik Indonesia no.20 tahun 2003 tentang Sisdiknas, Pendidikan agama secara langsung dimasukkan ke dalam kurikulum di sekolah-sekolah mulai dari sekolah dasar sampai universitas-universitas negeri.

Sementara untuk Dasar Religius Pendidikan Agama Islam itu adalah bersumber dari Al-Qur'an, sunnah dan ijtihad (ra'yu). Dasar inilah yang membuat pendidikan Islam menjadi ada, tanpa dasar ini tidak akan ada pendidikan Islam. Yang pertama adalah berdasarkan pada Al-Qur'an. Al-Qur'an ialah firman Allah berupa wahyu yang disampaikan oleh Jibril kepada Nabi Muhammad saw. Di dalamnya terkandung ajaran pokok sangat penting yang dapat dikembangkan untuk keperluan seluruh aspek kehidupan melalui ijtihad. Ajaran yang terkandung dalam Al-Qur'an itu terdiri dari dua prinsip besar, yaitu yang berhubungan dengan masalah keimanan yang disebut Aqidah, dan yang berhubungan dengan amal yang disebut dengan Syari'ah. Istilah-istilah yang sering biasa digunakan dalam membicarakan ilmu tentang syari'ah ini ialah :

(1) Ibadah untuk perbuatan yang langsung berhubungan dengan Allah.

(2) Mu'amalah untuk perbuatan yang berhubungan selain dengan Allah.

(3) Akhlak untuk tindakan yang menyangkut etika dan budi pekerti dalam pergaulan pendidikan, karena termasuk ke dalam usaha atau tindakan untuk membentuk manusia, termasuk ke dalam ruang lingkup mu'amalah. Pendidikan sangat penting karena ikut menentukan corak dan bentuk amal dan kehidupan manusia baik pribadi maupun masyarakat. $^{21}$

Landasan Religius berikutnya adalah As-Sunnah. As-Sunnah ialah perkataan, perbuatan ataupun pengakuan Rasul Allah SWT. Yang dimaksud dengan pengakuan ialah kejadian atau perbuatan orang lain yang di ketahui Rasulullah dan beliau membiarkan saja kejadian atau perbuatan. Sunnah merupakan ajaran kedua sesudah Al-Qur'an. Sunnah berisi petunjuk (pedoman) untuk kemaslahatan hidup manusia dalam segala

${ }^{21}$ Zakiah Daradjat, Ilmu Pendidikan Islam, cet. ke-5 (Jakarta: Bumi Aksara, 2004), hlm. 19-20. 
aspeknya, untuk membina umat menjadi manusia seutuhnya atau muslim yang bertakwa. Untuk itu Rasulullah menjadi guru dan pendidik utama bagi umatnya.22 Yang terakhir adalah Ijtihad; Ijtihad dalam pendidikan harus tetap bersumber dari Al-Qur'an dan Sunnah yang diolah oleh akal dari para ahli pendidikan Islam. Teori-teori pendidikan baru hasil ijtihad harus dikaitkan dengan ajaran Islam dan kebutuhan hidup. ${ }^{23}$

\section{Pengamalan Ibadah}

\section{Pengertian Pengamalan Ibadah}

Pengamalan adalah dari kata amal, yang berarti perbuatan, pekerjaan, segala sesuatu yang dikerjakan dengan maksud berbuat kebaikan. ${ }^{24}$ Dari pengertian di atas, pengamalan berarti sesuatu yang dikerjakan dengan maksud berbuat kebaikan, dari hal di atas pengamalan masih butuh objek kegiatan. Sedangkan pengertian ibadah menurut Hasby Ash Shiddieqy yaitu segala taat yang dikerjakan untuk mencapai keridhaan Allah dan mengharap pahala-Nya di akhirat. ${ }^{25}$ Dari uraian di atas, menggabungkan pengertian pengamalan dan pengertian ibadah, maka pengertian pengamalan ibadah yakni perbuatan yang dilakukan seorang hamba sebagai usaha menghubungkan dan mendekatkan diri kepada Allah SWT dengan taat melaksanakan segala perintah dan anjuran-Nya serta menjauhi segala larangan-Nya.

\section{Dasar Hukum Ibadah}

Jika kita renungi hakikat ibadah, kita pun yakin bahwa perintah beribadah itu pada hakikatnya berupa peringatan, memperingatkan kita menunaikan kewajiban terhadap Allah yang telah melimpahkan karunia-Nya.

Firman Allah swt:

Artinya : "Hai manusia, sembahlah Tuhanmu Yang telah menciptakanmu dan orangorang yang sebelummu, agar kamu bertakwa". (QS. Al Baqarah / 2: 21)26

\section{Ruang Lingkup dan Sistematika Ibadah}

Ibadah itu, mensyukuri nikmat Allah. Atas dasar inilah tidak diharuskan

22 Daradjat, Ilmu Pendidikan...., hlm. 21.

${ }^{23}$ Daradjat, Ilmu Pendidikan...., hlm. 22.

${ }^{24}$ W.J.S. Poerwadarminta, Kamus Umum Bahasa Indonesia, cet. ke-8 (Jakarta: Balai Pustaka, 1985), hlm. 33.

${ }^{25}$ Hasby Ash Shiddiqy, Kuliah Ibadah, cet. ke-1 (Semarang: PT.Pustaka Rizki Putra, 2000), hlm. 5 .

\footnotetext{
${ }^{26}$ Depag RI, Al-Qur'an dan Terjemahnya (Jakarta: CV. Penerbit J-Art, 2005), hlm. 5.
} 
baik oleh syara', maupun oleh akal beribadat kepada selain Allah, karena Allah sendiri yang berhak menerimanya, lantaran Allah sendiri yang memberikan nikmat yang paling besar kepada kita,yaitu hidup, wujud dan segala yang berhubungan dengan-Nya. ${ }^{27}$ Untuk mengetahui ruang lingkup ibadah ini tidak terlepas dari pemahaman terhadap pengertian itu sendiri. Oleh sebab itu menurut Ibnu Taimiyah (661-728H/1262-1327 M) seperti yang telah dikutip oleh Ahmad Ritonga, ibadah mencakup semua bentuk cinta dan kerelaan kepada Allah SWT, baik dalam perkataan maupun perbuatan, lahir dan bathin, maka yang termasuk ke dalam hal ini adalah shalat, zakat, puasa, haji, benar dalam pembicaraan, menjalankan amanah, berbuat baik kepada orangtua, menghubungkan silaturrahmi, memenuhi janji, amar ma'ruf nahi munkar, jihad terhadap orang kafir dan munafik, berbuat baik kepada tetangga, anak yatim, fakir miskin, dan ibn sabil, berdo'a, berzikir, membaca Al-Qur'an, ikhlas, sabar, sukur, rela menerima ketentuan Allah SWT, tawwakal, raja' (berharap atas rahmat), khauf (takut terhadap azab), dan lain sebagainya. ${ }^{28}$

a. Ruang lingkup ibadah yang dikemukakan Ibnu Taimiyah di atas cakupannya sangat luas, bahkan menurut beliau semua ajaran agama itu termasuk ibadah. Bilamana diklasifikasikan kesemuanya dapat menjadi beberapa kelompok saja, yaitu : Kewajibaban-kewajiban atau rukun-rukun syari'at seperti shalat, puasa, zakat dan haji.

b. Yang berhubungan dengan (tambahan dari) kewajiban-kewajiban di atas dalam bentuk ibadah-ibadah sunat, seperti zikir, membaca Al-Qur'an, doadan istigfar.

c. Semua bentuk hubungan sosial yang baik serta pemenuhan hak-hak manusia, seperti berbuat baik kepada orang tua, menghubungkan silaturrahmi, berbuat baik kepada anak yatim, fakir miskin dan ibnu sabil.

d. Akhlak Insaniyah, (bersifat kemanusiaan), seperti benar dalam berbicara, menjalankan amanah dan menepati janji.

e. Akhlak rabbaniyah (bersifat ketuhanan), seperti mencintai Allah swt, dan rasul- rasul-Nya, takut kepada Allah swt, ikhlas dan sabar terhadap hukumNya. ${ }^{29}$

\section{Tujuan Ibadah}

Ibadah mempunyai tujuan pokok dan tujuan tambahan. Tujuan pokoknya

${ }^{27}$ Ash Shiddiqy, Kuliah Ibadah..., hlm. 10.

${ }^{28}$ A. Rahman Ritonga, Figh Ibadah, cet. ke-2 (Jakarta: Gaya Media Pratama, 2002), hlm. 6.

${ }^{29}$ Ritonga, hlm. 7. 
adalah menghadapkan diri kepada Allah yang Maha Esa dan mengonsentrasikan niat kepada-Nya dalam setiap keadaan. Dengan adanya tujuan itu seseorang akan mencapai derajat yang tinggi di akhirat. Sedangkan tujuan tambahan adalah agar terciptanya kemaslahatan diri manusia dan terwujudnya usaha yang baik. Shalat umpamanya, disyari'atkan pada dasarnya bertujuan untuk menundukkan diri kepada Allah swt dengan ikhlas, mengingatkan diri dengan berzikir. Sedangkan tujuan tambahannya antara lain adalah untuk menghindarkan diri dari perbuatan keji dan munkar.

\section{HASIL PENELITIAN DAN PEMBAHASAN}

Metode Guru PAI Dalam Pembinaan Akhlak siswa di SMP N 4 Sekampung Lampung Timur

Berdasarkan hasil wawancara penulis dengan guru pendidikan agama Islam data yang diproleh oleh penulis adalah adalah sebagai berikut :

\section{Melalui Pembinaan disekolah}

Bentuk pembinaan akhlak yang dilakukan guru di sekolah adalah:

a. Setiap 15 menit sebelum pelajaran para siswa disuruh membaca suratsurat pendek. Tujuan dilakukannya hal tersebut agar semua siswa dapat membaca al-qur'an secara baik dan benar. (wawancara dengan Ibu Sumini)

b. Pada awal masuk pelajaran guru pendidikan agama Islam memberikan sebuah pertanyaan kepada siswa tentang materi pelajaran yang sudah diajarkan minggu sebelumnya. Tujuannya untuk mengingatkan kembali tentang materi yang sudah diterima oleh siswa dan juga untuk mengetahui seberapa jauh siswa tersebut memahami materi yang diajarkan.

c. Pada akhir pelajaran guru pendidikan agama Islam memberikan kesempatan kepada siswa untuk bertanya tentang materi yang diajarkan atau guru memberikan feed back kepada siswa untuk mengetahui seberapa jauh siswa menerima materi pelajaran yang diajarkan. Seperti yang diungkapkan oleh Ibu Sumini: "feed back ini bertujuan untuk mengetahui seberapa jauh siswa memahami materi pelajaran agama Islam yang disampaikan, untuk menguji seberapa siswa belajar dirumah." ${ }^{130}$

${ }^{30}$ Wawancara pada tanggal 28-5-2015 


\section{Melalui Pembinaan di Masyarakat}

Melalui kegiatan kemasyarakatan ini, pembinaan akhlak yang baik yaitu melalui kegiatan diluar jam pelajaran atau pun pada saat liburan sekolah, namun kegiatan ini menunjang nilai disekolah Adapun bentuk-bentuk kegiatan keagamaan yang dilakukan dalam pembinaan akhlakul karimah ialah:

a. Tugas membuat laporan kegiatan pondok romadhon yang diadakan disekolah dan diluar sekolah. (Wawancara dengan Ibu Sumini). ${ }^{31}$

b. Menulis kisah-kisah islami (Wawancara dengan Ibu Sumini). ${ }^{32}$

c. Latihan berqurban dan pada saat hari raya Idul Adha para siswa melaksanakan qurban di sekolah. Seperti yang diungkapkan Ibu Sumini: "Pada saat hari raya Qurban para siswa melaksanakan qurban disekolah dan saat itu juga para siswa membagikannya dimasyarakat sekitar sekolah dan juga pada saat menjelang hari raya Idul Fitri para siswa membagikan zakat fitrah kepada masyarakat sekitar dengan tujuan agar siswa tahu kehidupan masyarakat yang sebenarnya dan mengetahui siapa saja yang berhak memberi zakat fitrah". (wawancra dengan Ibu Sumini $)^{33}$

d. Pada saat hari-hari besar Islam para siswa diberi tugas untuk mengikuti kegiatan keagamaan yang ada di daerah masing-masing dan membuat buku laporannya. (wawancara dengan Ibu Sumini). ${ }^{34}$

\section{Metode Pembinaan Akhlak}

Dalam metode pembinaan akhlak ini guru agama Islam harus mempunyai cara-cara yang baik dan efisien dalam menjalin hubungan dengan para siswa, sebab jika tidak dengan cara yang benar siswa akan merasa jenuh dan bosan dengan guru yang mengajarkan mata pelajaran. Dalam pembinaan akhlak ini ada beberapa yaitu :

\section{Memberikan pelajaran atau nasihat}

Dalam memberikan pelajaran atau menyampaikan materi pelajaran guru pendidikan agama Islam menggunakan beberapa metode antara lain

1. Tanya jawab

${ }^{31}$ Wawancara pada tanggal 28-5-215

${ }^{32}$ Wawancara pada tanggal 28-5-2015

${ }^{33}$ Wawancara pada tanggal 28-5-2015

34 Wawancara pada tanggal 28-5-2015 
2. Penugasan

3. Diskusi kelompok

Dalam diskusi kelompok ini setiap siswa dikelompokkan menjadi beberapa kelompok untuk mencari tugas yang diberikan oleh guru pendidikan agama Islam. Misalnya:

a. Setiap kelompok siswa tersebut ditugaskan untuk mencari surat dalam Al-Qur'an seperti: carilah ayat tentang Isro' Mi'roj nabi Muhammad SAW surat Bani Isroil ayat 1.

b. Siswa ditugaskan mencari hokum bacaan atau tajwid seperti: tulislah contoh nun sukun atau tanwin pada surat Al-Lahab.

Apa yang disampaikan di atas didukung oleh Asnah ${ }^{35}$ yang menyatakan bahwa pembinaan di sekolah itu penting adanya, dengan adanya kemampuan super intelensi anak, sehingga memudahkan anak untuk dilakukan pembinaan dengan berbagai cara. Oleh karenanya guru harus menggunakan berbagai bentuk metode pembinaan agar setiap kecerdasan anak dapat terakomodir untuk dibina dalam melakukan pengamalan keagamaan.

\section{Membiasakan akhlak yang baik}

Sebagai guru terutama sebagai guru agama Islam maka harus mempunyai sifat dan sikap yang bagus dan juga kebiasaan yang bagus yang sesuai dengan norma agama dan masyarakat karena itulah guru agama harus menjadi sosok yang dapat ditiru tingkah lakunya dalam kehidupan sehari-harinya baik itu di dalam lingkungan sekolah maupun luar sekolah sebab membiasakan sikap yang baik sangat sulit sebab manusia adalah tempat melakukan salah dan benar oleh karena itu seorang guru agama harus sering intropeksi diri, dengan adanya intropeksi ini guru akan terhindar dari kesalahan dan juga kebiasaan yang kurang baik di para siswa maupun sesama pengajar. Seperti yang diungkapkan oleh Ibu Sumini: Sebagai guru agama Islam harus bertutur kata yang baik kepada muridnya sebab agama mempunyai peran besar dalam pendidikan oleh sebab itu guru agama harus bertutur kata yang baik pada muridnya yaitu dengan mendoakan muridnya dengan cara mengucapkan salam yang baik, sebab salam adalah doa keselamatan bagi orang Islam dan tak lupa pula guru

\footnotetext{
${ }^{35}$ Asnah, "Pengembangan Metode Pembelajaran PAI Berbasis Kecerdasan Majemuk," FITRAH:Jurnal Kajian Ilmu-Ilmu Keislaman 3, no. 2 (29 Desember 2017): 227-242.
} 
agama mencatat kejadian-kejadian yang negative atau pelanggaran terhadap tata tertib di sekolah dan menunjukkan kepada siswa yang bersangkutan. ${ }^{36}$

Karena sifat anak yang suka meniru terhadap orang-orang yang dikaguminya maka dalam pemberian materi yang berjalan dikelas maka guru agama islam harus menjadi panutan oleh para siswa dan sekaligus memberikan contoh yang nyata dalam kehidupan sehari baik memberikan contoh mengenai materi pelajaran ataupun tingkah laku sehari-hari. Hal juga diutarakan oleh Ibu Sumini: Karena saya sebagai guru agama Islam, saya selaku guru agama Islam harus memberikan contoh kepada anak didik saya dengan cara apabila waktu penyampaian materi pelajaran jika ada siswa yang gaduh atau berbuat yang aneh-aneh maka saya tidak langsung marah atau memberikan hukuman kepada anak yang berbuat onar dikelas tersebut akan tetapi memberikan nasehat jangan sampai anak tersebut berbuat onralagi dan jangan samapai menularkepada temannya yang lain. Mengingat guru pendidikan agama Islam harus memberikan contoh lebih bagus adari pada guru-guru yang lain. ${ }^{37}$

Hal senada juga disampaikan oleh Ibu Sumyati selaku Guru PAI Menjadi guru agama islam harus dapat menjadi contoh kepada semua anak didik sebab guru agama ini harus melakukan apa yang dikatakannya dan dalam penyampaian materi pelajaran ini anak didik langsung melihat secara langsung bagaimana sifat yang dimiliki oleh guru agama tersebut. Menurut Ibu Parjiah guru agama Islam harus mempunyai latar belakang yang bagus dan yang tak terlupakan adalah guru agama harus ilmu spiritualnya harus kuat dan jiwanya harus ihklas sebab dalam memberikan materi materi pelajaran gar membekas dalam hati yang diajar mengingat tugas seorang guru tidak hanya menyampaikan materi pelajaran akan tetapi tugas guru juga harus mendidik anak didik supaya berkelakuan bagus, dan guru agama mengajar tidak hanya sebatas teori tetapi juga praktek dalam kehidupan sehari-hari. ${ }^{38}$ Hal senada juga Bapak R. Arief Setyadi selaku Kepala Sekolah: Bahwa tugas dari dapa guru agama tidak hanya menyampaiakan materi pelajaran akan tetapi juga mendidik anak didik supaya berkelakuan bagus dan juga harus harus ihklas menjalankan tugas-tugas sebagai pendidik, guru agama juga harus berfikiran ke depan dalam mensosialisasikan ilmunya

${ }^{36}$ Wawancara pada tanggal 28-5-2015

37 Wawancara pada tanggal 28-5-2015

${ }^{38}$ Wawancara pada tanggal 28-5-2015 
sebab menurut Ibu Umu Amidahmanusia sebagai mahkluk social, artian guru agama harus dapat memberikan manfaat ilmunya kepada orang lain bukan untuk di simpan untuk dirinya sendiri. ${ }^{39}$

\section{Memberikan Reward (Hadiah) atau Sanksi}

Metode pemberian reward atau sangsi ini manakala siswa tidak dapat diberi pengarahan secara langsung maupun tidak langsung, maka sebagai guruharus mempunyai inisiatif untuk menanggulangi siswa tersebut. Tujuan diberikan metode ini adalah untuk memberikan efek jera pada anak didik untuk tidak melakukan hal-hal yang membawa kepada kemudhorotan bagi diri sendiri maupun orang lain. Oleh sebab itu sebagai guru mengetahui tingkah laku siswanya di sekolah dengan cara mencatat setiap kesalahannya dan memberikan sangsi kepada siswa yang melakukan kesalahan tujuan agar tidak terulang kembali kesalahan yang diperbuatnya dan orang lain untuk menirunya.

Pada saat penulis mengadakan penelitian saat itu ada kasus siswa ada yang berkelahi pada saat itu juga sama guru langsung ditangani agar perlakuan tersebut tidak terulang kembali atau bahkan menular kepada siswa yang lain. Dengan ditanganinya siswa secara langsung ini membuktikan bahwa pembinaan akhlak siswa di SMP N 4 Sekampung ini berjalan dengan baik hal ini terbukti dengan adanya penanganan secara langsung. Dan apabila siswa sering melakukan kesalahan maka pihak sekolah.

Bentuk-bentuk sangsi yang diberikan agar siswa tidak melakukan kesalahan lagi di SMP N 4 Sekampung antara lain:

Dalam memberikan sangsi kepada siswa yang tidak mengikuti acara kegiatan keagamaan maka saya selaku guru pendidikan agama islam menyuruh siswa untuk membeli Al-Qur'an tafsir dengan begitu, siswa di samping diberi hukuman dapat memberikan manfaat kepada siswa yang lain dengan membeli buku tafsir al-qur'an tersebut, jika siswa yang melanggar terlalu sering atau anak yang susah diatur atau siswa sering tidak masuk sekolah maka akan diberikan peringatan yaitu dimasukkan kedalam buku monitoring siswa dengan tujuan memberikan efek jera dengan melihat nama tercantum didalam buku monitoring (wawancara dengan Ibu Sumini) $)^{40}$

\footnotetext{
${ }^{39}$ Wawancara pada tanggal 3-6-2015

${ }^{40}$ Wawancara pada tanggal 28-5-2015
} 
Hal senada juga diperkuat oleh Bapak Sukido selaku Wakil kepala sekolah bidang kesiswaan:

Untuk siswa yang seing melanggar tata tertib disekolah akan dikenakan sangsi berupa namanya dimasukkan kedalam buku monitoring agar siswa jera dan kalau siswa masih membandel maka akan di beri surat peringatan lebih keras yaitu memberikan surat keterangan pengunduran diri pertama dan jika hal tesebut sering dikakuak maka diberi surat keterangan yang kedua yaitu pengunduran diri dengan diperkuat dengan materai di samping juga dimasukkan ke monitoring. ${ }^{41}$

Selanjutnya:

Bagi siswa yang terlambat lebih dari 15 menit disuruh pulang dan siswa disuruh mengajak orang tuanya kesekolah dengan tujuan keikutsertaan orang tua siswa dalam mengontrol siswa sebab sebab waktu dirumah atau diluar jam pelajaran lebih banyak dari pada di sekolah hal bertujuan agar tidak siswa tidak mengulangi hal yang serupa di lain waktu. (wawancara dengan Ibu Sumini) ${ }^{42}$

Hal senada juga dikemukakan oleh Sukido selaku Wakil Kepala Sekolah/ waka kesiswaan:

Memang kami selaku pengajar selalu menjaga kedisiplinan waktu agar siswa tertib, dan kami tidak pernah absen dalam mengabsen siswa yang tidak tidak masuk sekolah atau waktu jam pelajaran berlangsung dengan begitu anak akan terbiasa dengan peraturan yang tertib jika ada siswa yang berhalangan masuk atau tidak dapat masuk sekolah harus yang mengizinkan orang tuanya sebab di SMP N 4 Sekampung ini tidak melayani surat akan tetapi harus diizinkan orang tuanya dengan tujuan menjaga siswa tersebut tidak masuk memang ada keperluan atau tidak sebab banyak sekarang ini anak memberikan surat izin kepada sekolah untuk tidak masuk sekolah karena ada keperluan tetapi kenyataannya siswa tersebut main-main di luar sekolah, akan tetapi dengan program apabila anak tidak masuk sekolah yang mengizinkan orang tuanya secara otomatis orang tuanya pasti tahu kenapa anaknya tidak masuk ke sekolah. Dan kami juga memanggil orang tua siswa yang datangnya terlambat atau sering tidak masuk dengan tujuan yang sama agar siswa tersebut tidak mengulanginya lagi dan tidak ditiru oleh temannya yang lain. ${ }^{43}$

Hal senada juga diperkuat oleh Bapak R. Arief Setyadi selaku kepala sekolah. Beliau menegaskan bahwa untuk menanamkan kedisiplinan

${ }^{41}$ Wawancara pada tanggal 3-6-2015

42 Wawancara pada tanggal 28-5-2015

${ }^{43}$ Wawancara pada tanggal 28-5-2015 
belajar di SMP N 4 Sekampung ini adalah kesiplinan sebab kalau tidak disiplin hidupnya akan kacau, sebab di SMP N 4 Sekampung ini nantinya akan di beri hadiah kesejumlah perusahaan yang ada di Indonesia maka kedisiplinan harus ditekankankan disini. Jika kalau ada siswa yang tidak disiplin waktu terlambat maka akan dipanggil kekantor dan njika lebih dari 15 menit akan disuruh pulang dengan membawa orang tuanya, dengan kedisplinan ini siswa akan hidup disiplin. Dan juga bagi siswa yang terlambat atau tidak masuk sekolah dimasukkan kedalam buku monitoring agar para siswa yang banyak melakukan kesalahan akan ketahuan dan cepat di ambil tindakan supaya tidak berkelanjutan. ${ }^{44}$

Akan tetapi mengingat di SMP N 4 Sekampung ini adalah sekolah dasar ada juga imbalan atau hadiahnya bagi siswa yang menaati tata tertib disekolah dan juga berprestasi selama menempuh pendidikan di SMP N 4 Sekampung akan mendapatkan penghargaan antara lain siswa yang mendapatkannya ialah :

a. Bagi siswa yang tidak pernah melakukan kesalahan atau selalu aktif masuk sekolah dengan baik dan teratur.

b. Bagi siswa yang mendapatkan penghargaan ini akan di beri hadiah oleh pihak sekolah

c. Dan juga akan di promosikan ke sekolah SMA yang faporit oleh pihak sekolah

\section{Melalui Bimbingan dan Konseling}

Pembinaan akhlak yang baik yang dilakukan oleh Guru Pendidikan Agama Islam dengan memberikan bantuan terus menerus dalam memecahkan masalah-masalah yang dialami oleh siswa. Dalam pemecahan masalah ini memang tidak menjadi tanggung jawab sepenuhnya guru pendidikan agama Islam karena BP ini sebenarnya menjadi tugas dan tanggung jawab Guru BP/Wakil Kepala Sekolah tetapi antara guru pendidikan agama Islam dan BP selalau mengadakan komunikasi. Hal ini senada yang diutarakan Ibu Sumini yang menyatakan bahwa selaku Guru pendidikan agama Islam dengan Guru BP dan Wakil Kepala Sekolah bidang kwesiswaan selalu mengadakan

${ }^{44}$ Wawancara pada tanggal 3-6-2015 
komunikasi agar penanganan siswa ini berjalan dengan baik dan efisien, serta menjalin komunikasi antara guru satu dengan yang lainnya. ${ }^{45}$

Apa yang diungkapkan di atas sesuai yang disarankan oleh Risdawati ${ }^{46}$ yang menyatakan bahwa bimbingan dan konseling yang dilakukan terhadap anak didik hendaknya yang Islami, sehingga akan terbentuk akhlak anak-anak bangsa yang lebih baik. Jadi intinya bimbingan konseling secara Islami dipandang perlu untuk membina akhlak siswa sehingga pengamalan ibadahnya menjadi lebih baik.

\section{PENUTUP}

Metode guru pendidikan agama Islam dalam pembinaan akhlak siswa di SMP N 4 Sekampung Lampung Timur dengan beberapa cara yaitu melalui

a. Pendidikan di sekolah: yaitu dengan cara setiap mulai pelajaran berlangsung guru pendidikan agama Islam menyuruh siswa dengan membaca surat-surat pendek dalam al-qur'an, pada saat awal pelajaran guru pendidikan agama islam memulainya dengan mendoakan siswa dengan cara mengucapkan salam, sebab salam adalah do'a keselamatan bagi umat Islam dan guru pendidikan agama islam memberikan motivasi kepada siswa untuk belajar khususnya belajar ilmu agama Islam

b. Pendidikan di masyarakat: yaitu dengan cara siswa diajari langsung praktek ke lapangan dengan memberikan daging kurban kepada masyarakat sekitar SMP N 4 Sekampung, memberikan tugas pada saat hari besar islam yaitu pada saat bulan ramadhan dengan cara memberikan tugas mencatat kegiatan didaerah masing-masing untuk dilaporkan kepada pihak sekolah.

c. Metode pembinaan akhlak dengan cara (1) melalui pelajaran atau nasihat (2) membiasakan akhlak yang baik (3) melalui keteladanan yang baik (4) memilih teman yang baik, dan (5) memberi reward atau sangsi.

${ }^{45}$ Wawancara pada tanggal 30-5-2015

${ }^{46}$ Risdawati Siregar, "URGENSI KONSELING ISLAM DALAM PEMBINAAN AKHLAK," FITRAH:Jurnal Kajian Ilmu-ilmu Keislaman 8, no. 2 (2 Januari 2014): 319-330, https://doi.org/10.24952/fitrah.v8i2.355. 


\section{DAFTAR PUSTAKA}

Arifin, M. Filsafat pendidikan Islam. Jakarta: Bumi Aksara, 1997. https://books.google.co.id/books?id=101AgAACAAJ\&dq=M.+Arifin,+M.Ed,+Filsafat+Pendidikan+Islam\&hl=en \&sa=X\&ved=0ahUKEwiyzLLPiMzfAhWIMY8KHdr9BcYQ6AEIKTAA.

Ash Shiddiqy, Hasby. Kuliah Ibadah. cet. ke-1. Semarang: PT.Pustaka Rizki Putra, 2000.

Asnah. "Pengembangan Metode Pembelajaran PAI Berbasis Kecerdasan Majemuk." FITRAH:Jurnal Kajian Ilmu-Ilmu Keislaman 3, no. 2 (29 Desember 2017): 227-42.

D Marimba, Ahmad. Pengantar Filsafat Pendidikan Islam. Bandung: Al-Ma'arif, 1989.

Daradjat, Zakiah. Ilmu Pendidikan Islam. cet. ke-5. Jakarta: Bumi Aksara, 2004.

Depag RI. Al-Qur'an dan Terjemahnya. Jakarta: CV. Penerbit J-Art, 2005.

Departemen Agama RI. Al-Qur'an dan Terjemahannya. Bandung: Jum'anatul Art, 2005.

Departemen Diknas. Kamus Besar Bahasa Indonesia. Cet. ke-3. Jakarta: Balai Pustaka, 1994.

DEWAN PERWAKILAN RAKYAT REPUBLIK INDONESIA. Undang-undang Dasar 1945 HasilAmandemen. cet. ke-2. Jakarta: Sinar Grafika, 2005.

DEWAN PERWAKILAN RAKYAT REPUBLIK INDONESIA, dan PRESIDEN REPUBLIK INDON. Undang-undang Republik Indonesia Nomor 20 tahun 2003 tentang Sistem Pendidikan Nasional. Bandung: Fokus Media, 2006.

Forcese, Dennis Philip, dan Stephen Richer. Social Research Methode. New Jersey: Hall Inc-Ened Wood Cliffs, 1973.

Nizar, Samsul. Filsafat Pendidikan Islam, Pendekatan Historis, Teoritis dan Praktis. cet. ke-1. Jakarta: Ciputat Pers, 2002.

- - - Pengantar Dasar-dasar Pemikiran Pendidikan Islam. Jakarta: Gaya Media Pratama, 2000.

Poerwadarminta, W.J.S. Kamus Umum Bahasa Indonesia. cet. ke-8. Jakarta: Balai Pustaka, 1985. 
FITRAH Jurnal Kajian Ilmu-ilmu Keislaman

Vol. 04 No. 2 Desember 2018

Redaksi Sinar Grafika. Undang-Undang Sistem Pendidikan Nasional, UU RI NO.20 Tahun.2003. Jakarta: Sinar Grafika, 2003. http://buku-rahmadetail.blogspot.com/2014/09/undang-undang-sisdiknas-sistem.html.

Ritonga, A. Rahman. Fiqh Ibadah. cet. ke-2. Jakarta: Gaya Media Pratama, 2002.

Siregar, Risdawati. “URGENSI KONSELING ISLAM DALAM PEMBINAAN AKHLAK." FITRAH:Jurnal Kajian Ilmu-ilmu Keislaman 8, no. 2 (2 Januari 2014): 319-30. https://doi.org/10.24952/fitrah.v8i2.355.

Sumini, Guru PAI SMP N 4 Sekampung Lampung Timur. Ibadah dan Sholat, Tanggal 12Maret 2014.

- - - Pembinaan Akhlak. , Tanggal 17 Juli 2014, t.t.

Syah, Muhibbin. Psikologi Pendidikan dengan Pendekatan Baru. cet. ke-7. Bandung: PT. Remaja Rosdakarya, 2002.

Tafsir, Ahmad. Ilmu Pendidikan dalam Perspektif Islam. cet. ke-1. Bandung: Remaja Rosdakarya, 1992.

Usman, M. Basyiruddin. Metodologi Pembelajaran Agama Islam. cet. ke-1. Jakarta: Ciputat Pers, 2002. 